\title{
Synthesis, characterisation of few N-substituted 1,8-naphthalimide derivatives and their copper(II) complexes
}

\author{
NILOTPAL BAROOAH, CHANDAN TAMULY and JUBARAJ B BARUAH* \\ Department of Chemistry, Indian Institute of Technology, Guwahati 781 039, India \\ e-mail: juba@iitg.ernet.in
}

\begin{abstract}
A few 1,8-naphthalimide derivatives with phenyl (1), benzyl (2), 3,4-dimethoxyphenyl ethyl (3), 4-pyridyl (4), 2-hydroxy ethyl (5), 4-pyridylmethyl (6) groups attached to the nitrogen atom are synthesized and characterized. Cyclic voltammograms of all these compounds show one-electron reversible redox cycle ( $-1.24 \mathrm{~V}$ to $-1.18 \mathrm{~V})$ due to formation of anion radicals. However, in the case of (5), quenching of this redox process occurs when polyhydroxy-aromatic compounds such as 1,3-dihydroxy benzene and 1,3,5-trihydroxybenzene are added. Copper complexes, namely bis- $\{\mathrm{N}-(4$-pyridylmethyl $) 1,8$-naphthalimide $\}$ copper (II) perchlorate (8), bis- $\{\mathrm{N}$-(4-pyridylmethyl)1,8-naphthalimide $\}$ copper (II) perchlorate (9) and bis- $\{\mathrm{N}-(4-$ pyridylmethyl)phthalimide $\}$ copper (II) perchlorate (10) are synthesized and characterised. The complexes (8) and (9) show reversible redox couple of the ligand without any significant interaction with the redox active copper (II) centre.
\end{abstract}

Keywords. N-substituted 1,8-naphthalimides; $\mathrm{Cu}$ (II) complexes of $\mathrm{N}$-substituted 1,8-naphthalimides; redox active $\mathrm{Cu}(\mathrm{II})$ centre.

\section{Introduction}

Imides of aromatic dicarboxylic acids are important in the construction of macromolecules ${ }^{1,2}$ as well as supramolecular assembly. ${ }^{3-7}$ Ease of formation of imides from the corresponding anhydrides has made them simple to synthesise. ${ }^{8,9}$ They are useful fluoroprobes for various studies ${ }^{8,10-14}$ and also serve as precursors for protection of the amine group. ${ }^{15-19}$ Photochemistry of phthalimide derivatives results in selective organic transformations. ${ }^{20,21}$ Phthalimide analogues such as naphthalimide derivatives are electroactive, and there is scope for their study in supramolecular environments. ${ }^{3-7}$ 1,8-Naphthalimides also show one-electron reversible redox property. ${ }^{23-25} \mathrm{We}$ have demonstrated that N-2-hydroxyethyl phthalimide forms an adduct with 1,3-dihydroxy benzene and 1,3,5-trihydroxybenzene, and has an interesting supramolecular structure. ${ }^{26}$ Thus, understanding of the redox behaviour of 1,8-naphthalimides having different groups anchored to the nitrogen atom is expected to throw light on their implications on supramolecular binding and this also would provide information on their suitability as electrochemical probes. This paper deals with the synthetic and spec-

Dedicated to the memory of the late Professor Bhaskar G Maiya

*For correspondence troscopic properties of a few N-substituted 1,8naphthalimides and their co-ordination chemistry with copper (II).

\section{Experimental}

\subsection{Synthesis of N-(4-pyridylmethyl)1,8- naphthalimide (6)}

To a solution of 1,8-naphthalic anhydride $(0.99 \mathrm{~g}$, $5 \mathrm{mmol}$ ) in tetrahydrofuran (THF) $(25 \mathrm{ml})$ 4-pyridylmethyl amine $(0.54 \mathrm{~g}, 5 \mathrm{mmol})$ was added drop wise at room temperature. The solution was stirred for six hours at room temperature to obtain an offwhite coloured precipitate. The precipitate was collected and washed with THF $(10 \mathrm{ml})$ and dried in air. It was finally recrystallised from a mixture of ethanol and chloroform (2:8 mixture). Yield: $1.38 \mathrm{~g}$ (97\%). Elemental analysis Calcd. for $\mathrm{C}_{18} \mathrm{H}_{10} \mathrm{~N}_{2} \mathrm{O}_{2}$, C, $75.52, \mathrm{H}, 3 \cdot 49, \mathrm{~N}, 9.79 \%$ : found $\mathrm{C}, 75.46, \mathrm{H}, 3.42$, $\mathrm{N}, 9 \cdot 65 \%$. Spectroscopic details are given in table 1 .

\subsection{Synthesis of N-(4-pyridylmethyl)phthalimide (7)}

Finely ground phthalic anhydride $(1.48 \mathrm{~g}, 10 \mathrm{mmol})$ was dissolved in THF. To this solution, 4-pyridylmethyl amine $(1.08 \mathrm{~g}, 10 \mathrm{mmol})$ was added drop- 
Table 1. Spectroscopic properties of naphthalimide derivatives.

\begin{tabular}{|c|c|c|c|}
\hline Structure & NMR signals (ppm, $\mathrm{CDCl}_{3}$ ) & $\begin{array}{l}\text { Characteristic IR-frequencies } \\
\qquad\left(\mathrm{KBr}, \mathrm{cm}^{-1}\right)\end{array}$ & $\begin{array}{l}E_{1 / 2} ;(\ddot{\mathrm{A}} E \\
\left.i p_{c} / i p_{a}\right)^{\#}\end{array}$ \\
\hline 1 & $\begin{array}{l}{ }^{1} \mathrm{H}: 8 \cdot 63(d, J=8 \mathrm{~Hz}, 2 \mathrm{H}), 8 \cdot 27(d m, \\
J=8 \mathrm{~Hz}, 2 \mathrm{H}), 7 \cdot 78(t, J=8 \mathrm{~Hz}, 2 \mathrm{H}), \\
7 \cdot 57-7 \cdot 47(m, 3 \mathrm{H}), 7 \cdot 31(d m, J=6 \mathrm{~Hz}, 2 \mathrm{H}) \\
{ }^{13} \mathrm{C}: 163 \cdot 73,151 \cdot 22,143 \cdot 52,134 \cdot 96,132 \cdot 09, \\
128 \cdot 71,128 \cdot 0,127 \cdot 35,124 \cdot 30,122 \cdot 53\end{array}$ & $\begin{array}{l}3073(w), 1701(s), 1655(s), \\
1583(s), 1501(s), 1440(s), 1352(s) \\
1335(s), 1183(s), 1112(s), 1076(m) \\
1025(m), 784(s)\end{array}$ & $\begin{array}{c}-1260 \mathrm{mV} \\
(80 \mathrm{mV} \\
1 \cdot 18)\end{array}$ \\
\hline 2 & $\begin{array}{l}{ }^{1} \mathrm{H}: 8 \cdot 62(d, J=6 \mathrm{~Hz}, 2 \mathrm{H}), 8 \cdot 21(m, 2 \mathrm{H}), \\
7 \cdot 74(m, 2 \mathrm{H}), 7 \cdot 55(t, J=6 \mathrm{~Hz}, 2 \mathrm{H}), \\
7 \cdot 32-7 \cdot 23(m, J=6 \mathrm{~Hz}, 3 \mathrm{H}), 5 \cdot 39(s, 2 \mathrm{H}) \\
{ }^{13} \mathrm{C}: 164 \cdot 28,137 \cdot 51,134 \cdot 10,131 \cdot 66,131 \cdot 48, \\
129 \cdot 23,128 \cdot 0,128 \cdot 61,127 \cdot 68,127 \cdot 06, \\
122 \cdot 75,43 \cdot 93\end{array}$ & $\begin{array}{l}3061(w), 2965(w), 1687(s), 1652(s) \\
1586(s), 1495(w), 1440(s), 1374(s) \\
1228(s), 1177(m), 1137(m), 1066(s) \\
945(s), 778(s)\end{array}$ & $\begin{array}{c}-1201 \mathrm{mV} \\
(80 \mathrm{mV} \\
0 \cdot 948)\end{array}$ \\
\hline & $\begin{array}{l}{ }^{1} \mathrm{H}: 8 \cdot 6(d, J=6 \mathrm{~Hz}, 2 \mathrm{H}), 8 \cdot 2(d, J=6 \mathrm{~Hz}, \\
2 \mathrm{H}), 7 \cdot 7(t, J=6 \mathrm{~Hz}, 2 \mathrm{H}), 6 \cdot 9(m, 3 \mathrm{H}), \\
4 \cdot 4(m, 2 \mathrm{H}), 3 \cdot 8(s, 6 \mathrm{H}) 3 \cdot 0(m, 2 \mathrm{H}) \\
{ }^{13} \mathrm{C}: 163 \cdot 61,148 \cdot 44,148 \cdot 17,133 \cdot 61,131 \cdot 19, \\
130 \cdot 98,130 \cdot 82,127 \cdot 72,126 \cdot 6,120 \cdot 64, \\
111 \cdot 81,110 \cdot 94,55 \cdot 72,55 \cdot 67,41 \cdot 83,33 \cdot 76\end{array}$ & $\begin{array}{l}3083(w), 2991(m), 2945(m), \\
2843(m), 1669(s), 1665(s), 1598(s), \\
1521(s), 1450(s), 1393(s), 1347(s), \\
1271(s), 1235(s), 1153(s), 1030(s), \\
948(m), 851(m), 784(s)\end{array}$ & $\begin{array}{c}-1195 \mathrm{mV} \\
(80 \mathrm{mV} \\
1 \cdot 2)\end{array}$ \\
\hline 4 & $\begin{array}{l}{ }^{1} \mathrm{H}: 8 \cdot 83(d, J=6 \cdot 4 \mathrm{~Hz}, 2 \mathrm{H}), 8 \cdot 64(d, \\
J=6 \cdot 4 \mathrm{~Hz}, 2 \mathrm{H}), 8 \cdot 32(d, J=6 \cdot 4 \mathrm{~Hz}, 2 \mathrm{H}), \\
7 \cdot 81(t, J=6 \cdot 4 \mathrm{~Hz}, 2 \mathrm{H}), 7 \cdot 32(d m, J=6 \mathrm{~Hz}, \\
{ }^{2 \mathrm{H})} \\
{ }^{13} \mathrm{C}: 163 \cdot 64,150 \cdot 28,148 \cdot 49,136 \cdot 59,133 \cdot 89, \\
132 \cdot 61,131 \cdot 18,127 \cdot 82,126 \cdot 63,123 \cdot 05,121.97\end{array}$ & $\begin{array}{l}3068(w), 1711(s), 1670(s), 1588(s) \\
1352(s), 1240(s), 1189(s) \\
861(s), 789(s)\end{array}$ & $\begin{array}{c}-1180 \mathrm{mV} \\
(80 \mathrm{mV} \\
1 \cdot 25)\end{array}$ \\
\hline & $\begin{array}{l}{ }^{1} \mathrm{H}: 8 \cdot 6(d, J=6 \mathrm{~Hz}, 2 \mathrm{H}) 8 \cdot 22(d, J=6 \mathrm{~Hz}), \\
7 \cdot 8(t, J=6 \mathrm{~Hz}), 4 \cdot 5(m, 2 \mathrm{H}), 4 \cdot 0(m, 2 \mathrm{H}), \\
2 \cdot 4(\text { broad } s, 1 \mathrm{H}) \\
{ }^{13} \mathrm{C}: 165,134,131,128,126,122,61,42\end{array}$ & $\begin{array}{l}3483(s), 3073(w), 2966(w), 2879(w) \\
1706(s), 1660(s), 1593(s), 1445(m) \\
1388(s), 1327(s), 1235(s), 1081(w) \\
1035(s), 907(w), 779(s)\end{array}$ & $\begin{array}{c}-1195 \mathrm{mV} \\
(85 \mathrm{mV} \\
1 \cdot 20)\end{array}$ \\
\hline $\begin{array}{ll}\mathrm{L}_{1} & \end{array}$ & $\begin{array}{l}{ }^{1} \mathrm{H}: 8 \cdot 6(d, J=7 \cdot 2 \mathrm{~Hz}, 2 \mathrm{H}), 8 \cdot 5(d, J=6 \mathrm{~Hz}, \\
2 \mathrm{H}), 8 \cdot 2(d, J=8 \mathrm{~Hz}, 2 \mathrm{H}), 7 \cdot 7(t, J=7 \cdot 2 \mathrm{~Hz}, \\
2 \mathrm{H}), 7 \cdot 3(d, J=6 \mathrm{~Hz}, 2 \mathrm{H}), 5 \cdot 3(s, 2 \mathrm{H}) \\
\\
{ }^{13} \mathrm{C}: 163 \cdot 59,149 \cdot 53,145 \cdot 59,134 \cdot 03,131 \cdot 26, \\
127 \cdot 75,126 \cdot 67,122 \cdot 94,121 \cdot 82,42 \cdot 78\end{array}$ & $\begin{array}{l}3083(w), 3022(w), 2966(w) \\
17778(m), 1724(v s), 1706(s) \\
1655(s), 1598(s), 1516(s) \\
1434(s), 1383(s), 1312(s) \\
1240(s), 1178(s), 948(s), 779(s)\end{array}$ & $\begin{array}{c}-1240 \\
(70 \mathrm{mV} \\
1 \cdot 01)\end{array}$ \\
\hline $\begin{array}{l}\| \\
\mathrm{O} \\
\mathrm{L}_{2} \\
7\end{array}$ & $\begin{array}{l}{ }^{1} \mathrm{H}: 8 \cdot 5(d, J=5 \cdot 6 \mathrm{~Hz}, 2 \mathrm{H}), 7 \cdot 8(d d, J=8 \cdot 4, \\
4 \mathrm{~Hz}, 4 \mathrm{H}), 7 \cdot 29(d, J=6 \cdot 4 \mathrm{~Hz}, 2 \mathrm{H}), 4 \cdot 9(s, \\
2 \mathrm{H}) \\
{ }^{13} \mathrm{C}: 167 \cdot 85,150 \cdot 31,144 \cdot 97,134 \cdot 47,132 \cdot 02, \\
123 \cdot 77,123 \cdot 12,40 \cdot 85\end{array}$ & $\begin{array}{l}3099(w), 3037(w), 1718(w), \\
1706(v s), 1609(w), 1419(s), 1393(s) \\
1317(w), 1112(m), 943(s), 794(m) \\
728(s)\end{array}$ & - \\
\hline
\end{tabular}

${ }^{\#}$ All electrode potentials reported are measured in acetonitrlie $(1 \mathrm{mmol})$, TBAP as supporting electrolyte, platinum electrodes as working electrodes and $\mathrm{Ag} / \mathrm{AgCl}$ as reference electrode (+ve scan, $100 \mathrm{mV} / \mathrm{s}$ ) and are with respect to the ferrocene couple 
wise. The reaction mixture became warm and an off-white precipitate was obtained. The reaction mixture was stirred for three hours for completion of the reaction. The precipitate thus formed was filtered and dried. The precipitate was recrystallised from an ethanol-chloroform mixture $(1: 1)$ to give $\mathrm{N}$-(4pyridylmethyl)phthalimide. Yield: $2 \cdot 3 \mathrm{~g}$ (97\%). Elemental analysis: Calcd. for $\mathrm{C}_{14} \mathrm{H}_{10} \mathrm{~N}_{2} \mathrm{O}_{2}, C$, $70 \cdot 59, \mathrm{H}, 4 \cdot 20, \mathrm{~N}, 11.76 \%$; found $\mathrm{C}, 70 \cdot 52, \mathrm{H}, 4 \cdot 19$, $\mathrm{N}, 11 \cdot 58 \%$.

Compounds 1-5 were prepared by a procedure similar to that used for $\mathbf{6}$ and $\mathbf{7}$.

\subsection{Synthesis of bis-\{N-(4-pyridylmethyl)1,8- naphthalimide\} copper (II) perchlorate $(\mathbf{8})$}

Copper (II) perchlorate hexahydrate $(0 \cdot 19 \mathrm{~g}$, $0.5 \mathrm{mmol})$ was dissolved in dry acetonitrile $(5 \mathrm{ml})$ and a solution of $\mathrm{N}$-(4-pyridylmethyl)1,8-naphthalimide $(0.12 \mathrm{~g}, 1 \mathrm{mmol})$ in dry acetonitrile $(2 \mathrm{ml})$ was added dropwise with stirring at room temperature. The dark blue solution was stirred for three hours to obtain a light-blue precipitate. The precipitate was washed with diethylether and dried in air $(0.18 \mathrm{~g}$, $71 \%)$. UV-Vis $603 \mathrm{~nm}\left(759 \mathrm{~mol}^{-1} \mathrm{~cm}^{2}\right)$. Molar conductance: $\left(\mathrm{CH}_{3} \mathrm{CN}, 25^{\circ} \mathrm{C}\right) 30 \cdot 84 \mathrm{ohm}^{-1} \mathrm{~mol}^{-1} \mathrm{~cm}^{2}$.

\subsection{Synthesis of bis-(N-(4-pyridylmethyl) 1,8- naphthalimide) copper(II)nitrate dihydrate (9)}

To a solution of copper (II) nitrate trihydrate $(0.24 \mathrm{~g}$, $1 \mathrm{mmol})$ in methanol $(10 \mathrm{ml})$, a solution of $\mathrm{N}-(4-$ pyridylmethyl) 1,8 -naphthalimide $(0.68 \mathrm{~g}, 2 \mathrm{mmol})$ in acetonitrile $(5 \mathrm{ml})$ was added dropwise. The reaction mixture was stirred at room temperature for two hours to obtain a light-blue coloured precipitate. The precipitate was filtered and redissolved in $\mathrm{CH}_{3} \mathrm{CN}$ (10 ml) by warming. On cooling, a microcrystalline precipitate was obtained as the desired complex (yield $0.32 \mathrm{~g}, 37 \%$ ). Spectroscopic data of the complex are given in table 2. Molar conductance $\left(\mathrm{CH}_{3} \mathrm{CN}\right.$, $\left.25^{\circ} \mathrm{C}\right): 42 \cdot 2 \mathrm{ohm}^{-1} \mathrm{~mol}^{-1} \mathrm{~cm}^{2}$.

The complex (10) was prepared in a similar manner to (8) to obtain $58 \%$ yield. Molar conductance of (10) in acetonitrile $\left(25^{\circ} \mathrm{C}\right): 34 \cdot 2 \mathrm{ohm}^{-1} \mathrm{~mol}^{-1} \mathrm{~cm}^{2}$.

\section{Results and discussion}

Spectroscopic properties of a series of $\mathrm{N}$-substituted 1,8-naphthalamides synthesized are listed in table 1.
Cyclic voltammograms of all these compounds in acetonitrile with tetrabutyl ammonium perchlorate (TBAP) as supporting electrolyte show reversible redox couple, below. The redox couple is attributed to the formation of a radical anion involving a oneelectron redox process as below, ${ }^{23-25}$

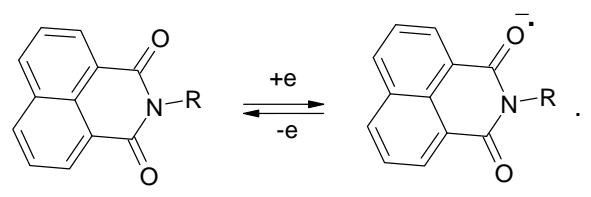

From the electrochemical data shown in table 1 it is clear that groups attached to the nitrogen atom in the ring of 1,8-naphthalimide do not significantly affect the redox property of these compounds. In the case of N-2-hydroxyethyl 1,8-naphthalimide it is observed that the redox couple is affected by the addition of poly-hydroxy aromatic compound. Thus the reversible redox couple present in the parent molecule (5) is lost when 1,3-dihydroxy benzene or 1,3,5-trihydroxybenzene is added to a solution of N-2hydroxy ethyl 1,8-naphthalimide. This is in accordance with the results on the formation of $1: 1$ adduct of N-2-hydroxy ethylphthalimide with 1,3-dihydroxybenzene or 1,3,5-trihydroxy benzene. ${ }^{26}$ Quenching of the redox process occurs due to the formation of adduct of 1,8-naphthalimide derivative (5) with polyhydroxy aromatic compounds. It has been suggested that the binding of $o$-quinone derivatives to the dendrimeric hosts leads to lowering of their reduction potential and stabilization of the anionic radicals. ${ }^{27}$ The ${ }^{1} \mathrm{H}$ NMR spectrum of N-2-hydroxyethyl-1,8-naphthalimide was recorded in deuterated chloroform solution without 1,3-dihydroxybenzene and with its addition at different concentration ratios. This study did not differentiate between chemical shifts of the original substrates and adducts, except that broadening of the $\mathrm{OH}$-signal present at $3 \mathrm{ppm}$ occurs when 1,3-dihydroxybenzene is added, leaving the other signals intact at the original positions. This suggests that there is a slow exchange of protons between the 1,3-dihydroxybenzene and N-2-hydroxyethyl 1,8-naphthalimide.

From the above discussion it is clear that the substituent attached to the nitrogen atom in 1,8naphthalimide does not significantly affect the redox property, but the supramolecular assembly formation can affect the redox potential. With this background, we extended our study to incorporate the 1,8naphthalimide unit in the copper complex with a 
Table 2. Spectroscopic data for copper complexes $(\mathbf{8}-\mathbf{1 0})$.

\begin{tabular}{|c|c|c|c|c|}
\hline Complex & Elemental analysis (\%) & $\mathrm{IR}\left(\mathrm{KBr}, \mathrm{cm}^{-1}\right)$ & $\begin{array}{l}\text { TG (temperature } \\
\text { and weight loss) }\end{array}$ & $\begin{array}{c}E_{1 / 2} ; \\
\left(\ddot{\mathrm{A}} E i p_{c} / i p_{a}\right)^{\#}\end{array}$ \\
\hline 8 & $\begin{array}{l}\text { Found: } \mathrm{C}, 51.62 \mathrm{H}, 2 \cdot 68, \mathrm{~N}, 6.27 \\
\text { Calcd. for } \mathrm{ML}_{2}\left(\mathrm{ClO}_{4}\right)_{2} \text { : } \\
\mathrm{C}, 51 \cdot 52 ; \mathrm{H}, 2 \cdot 86 ; \mathrm{N}, 6.68\end{array}$ & $\begin{array}{l}2930(s), 2858(s), 1701(s), \\
1665(s), 1624(s), 1440(s), \\
1388(s), 1245(s), 1112(s), \\
1061(s), 963(s), 789(s)\end{array}$ & $\begin{array}{l}225-270^{\circ} \mathrm{C} ; 78 \cdot 12 \% \\
\text { [calcd. } 78 \cdot 55 \% \text { for loss } \\
\text { of } 2 \mathrm{~L} \text { followed by loss } \\
\text { of } \mathrm{HClO}_{4} \text { via hydrolytic } \\
\text { reaction to give } \\
\mathrm{Cu}(\mathrm{OH}) \mathrm{ClO}_{4} \text { ] }\end{array}$ & $\begin{array}{c}-1240 \mathrm{mV} \\
(81 \mathrm{mV} \\
1 \cdot 32)\end{array}$ \\
\hline 9 & $\begin{array}{l}\text { Found: } \mathrm{C}, 53 \cdot 6, \mathrm{H}, 3 \cdot 27, \mathrm{~N}, 7 \cdot 49 \\
\text { Calcd. for } \mathrm{ML}_{2}\left(\mathrm{NO}_{3}\right)_{2} \cdot 2 \mathrm{H}_{2} \mathrm{O} \\
\mathrm{C}, 54 \cdot 03, \mathrm{H}, 3 \cdot 50, \mathrm{~N}, 7 \cdot 00\end{array}$ & $\begin{array}{l}3452(b w), 3063(w), 2976(w), \\
1701(s), 1665(s), 1496(s), \\
1440(s), 1387(s), 1291(s), \\
1235(s), 1173(s), 1015(s), \\
953(s), 779(s)\end{array}$ & $\begin{array}{l}50-80{ }^{\circ} \mathrm{C} ; 3 \cdot 9 \% \text { (calcd. } \\
4 \cdot 5 \% \text { for loss of water } \\
\text { of crystallization) } \\
240-300^{\circ} \mathrm{C} ; 33 \cdot 23 \% \\
\text { (calcd. } 36 \cdot 02 \% \text {, for loss } \\
\text { of one ligand) } \\
240-430^{\circ} \mathrm{C} ; 31 \cdot 87 \% \\
\text { (calcd. } 36 \cdot 02 \% \text { for loss } \\
\text { of another ligand) } \\
450-600^{\circ} \mathrm{C} ; 17 \cdot 08 \% \\
{[\text { calcd. } 16 \% \text {, for loss of }} \\
\mathrm{HNO} \text { via reaction with } \text { moisture to give } \\
\left.\mathrm{Cu}(\mathrm{OH}) \mathrm{NO}_{3}\right]\end{array}$ & $\begin{array}{c}-1238 \mathrm{mV} \\
(80 \mathrm{mV} \\
1.34)\end{array}$ \\
\hline 10 & $\begin{array}{l}\text { Found: } \mathrm{C}, 45 \cdot 33, \mathrm{H}, 2 \cdot 82, \mathrm{~N}, 7 \cdot 10 \\
\text { Calcd. for } \mathrm{ML}_{2}\left(\mathrm{ClO}_{4}\right)_{2} \\
\mathrm{C}, 44 \cdot 89 ; \mathrm{H}, 2 \cdot 67 ; \mathrm{N}, 7 \cdot 48\end{array}$ & $\begin{array}{l}2930(s), 2858(s), 1778(w), \\
1726(s), 1624(m), 1440(s), \\
1404(s), 1122(s), 1050(s), \\
943(m), 723(s)\end{array}$ & $\begin{array}{l}220-450^{\circ} \mathrm{C} ; 73 \cdot 59 \% \\
\text { [calcd. } 75 \cdot 76 \% \text { for loss } \\
\text { of two-ligands, followed } \\
\text { by hydrolytic cleavage } \\
\text { to release } \mathrm{HClO}_{4} \\
\text { and form } \mathrm{Cu}(\mathrm{OH}) \mathrm{ClO}_{4} \text { ] }\end{array}$ & $\begin{array}{c}-292 \mathrm{mV} \\
(270 \mathrm{mV} \\
0 \cdot 279)\end{array}$ \\
\hline
\end{tabular}

\#All electrode potentials reported are measured in acetonitrlie $(1 \mathrm{mmol})$, TBAP as supporting electrolyte, platinum electrodes as working electrodes and $\mathrm{Ag} / \mathrm{AgCl}$ as reference electrode (+ve scan, $100 \mathrm{mV} / \mathrm{s}$ ) and are with respect to the ferrocene couple. ${ }^{\$}$ Caution! The perchlorate complexes are potentially explosive

view to have a redox active metal centre that may in turn affect the electrochemistry of the 1,8-naphthalimide unit. Since the 1,8-naphthalimide is not a good enough nitrogen donor to form the complex, we attempted synthesizing copper (II) complexes with ligand (5) having a pyridine group attached to the 1,8-naphthalimide unit. This ligand did not give properly isolable copper complexes, presumably due to steric congestion. However, ligand (6) and (7) form well-characterisable copper (II) complexes with nitrate and perchlorate as anion (see (2) below). They have good solubility in methanol, acetonitrile etc. to study them in solution. In each case a $\mathrm{ML}_{2} \mathrm{X}_{2}$ type complex (where $\mathrm{L}=$ ligand and $\mathrm{X}=$ anion) is observed with or without water of crystallisation.

$$
\mathrm{L}+\mathrm{CuX}_{2} \mathrm{nH}_{2} \mathrm{O} \longrightarrow \underset{\mathbf{8}-\mathbf{1 0}}{\mathrm{L}_{2} \mathrm{CuX}_{2}}
$$

when

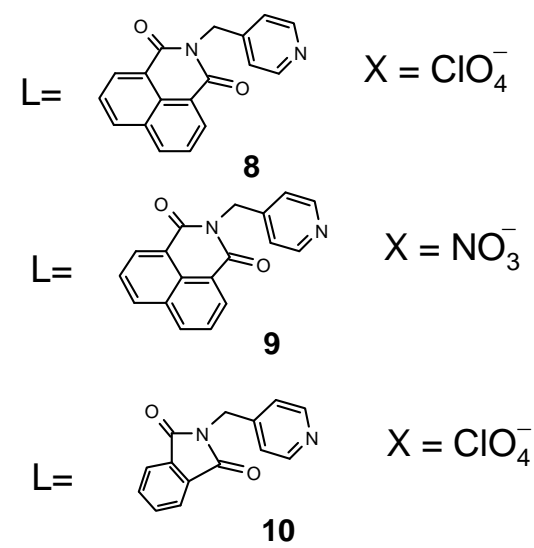

The molar conductance value of each complex has value ranging from $20-40 \mathrm{ohm}^{-1} \mathrm{~cm}^{2}$ depending on solvent under consideration. This suggests that they are nonionic. This is attributed to the fact that the nitrate and perchlorate groups in these complexes are coordinated to the copper (II) ion in both mono- 
dentate and bidentate fashion to complete five coordination geometry. Such observation is common in copper (II) coordination chemistry, as many pentacoordinated copper (II) complexes with overall $\mathrm{N}_{2} \mathrm{O}_{3}$ co-ordination around copper (II) is well documented. ${ }^{28,29}$ The minimised energy structure of $(\mathbf{9})$ having two N-(4-pyridylmethyl)-1,8-naphthalimide ligands along with two nitrato groups attached to copper (II) ion is shown in figure 1. The elemental analysis of these complexes suggests that in the case of nitrate complex (9) there are two molecules of water of crystallization. This is supported by loss of weight from (9) observed at relatively low temperature (50$80^{\circ} \mathrm{C}$ ) and is further supported by observation of broad and weak absorbance in IR spectra at $3452 \mathrm{~cm}^{-1}$ due to $\mathrm{OH}$-stretching vibrations. A freshly prepared and well-dried sample of (9) is devoid of these features; but on standing the compound under ordinary conditions rapidly picks up moisture.

Thermogravimetry shows that perchlorate complexes (8) and (10) lose the ligands at relatively low temperature; for example in the case of $(\mathbf{8})$ it occurs at $225-270^{\circ} \mathrm{C}$ whereas in the case of $(\mathbf{1 0})$ it occurs at $220-250^{\circ} \mathrm{C}$. Final weight loss in both the compounds corresponds to formation of $\mathrm{Cu}(\mathrm{OH}) \mathrm{ClO}_{4}$. Presumably this occurs, through a hydrolytic reaction of anhydrous copper (II) perchlorate formed as intermediate and liberation of $\mathrm{HClO}_{4}$. There is a difference in the mass loss pattern between the two complexes; in the case of (10) weight loss is spread over the range $220-460^{\circ} \mathrm{C}$, of which the loss at the region $220-250^{\circ} \mathrm{C}$ is sharp and corresponds to loss of the two neutral ligands and weight loss beyond $250^{\circ} \mathrm{C}$ corresponds to hydrolytic cleavage with traces of moisture in the nitrogen gas. However, the loss of weight in the case of (9) occurs in a very narrow region; there is a sharp loss of weight at $225^{\circ} \mathrm{C}$, with a small increase in weight $\left(226-235^{\circ} \mathrm{C}, 1.9 \%\right)$, followed by loss of weight $\left(226-270^{\circ} \mathrm{C}, 3.9 \%\right)$, this presumably happens due to a loss of ligand and the

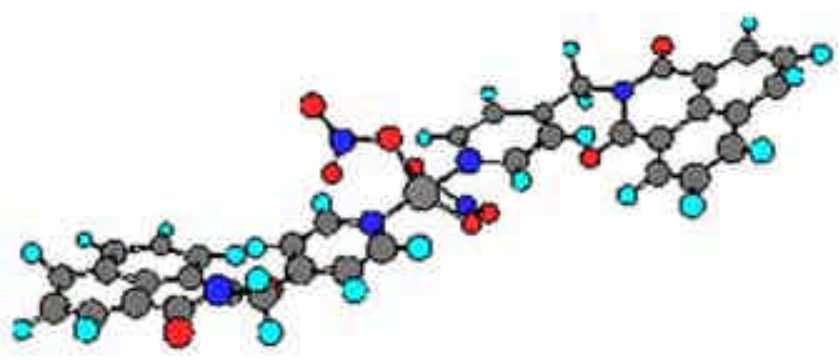

Figure 1. Energy minimized structure of (9). hydrolytic reaction of anhydrous copper (II) perchlorate over a very narrow temperature range. It is a well established fact that anhydrous copper (II) perchlorate is generally produced in solution and is highly reactive. ${ }^{30}$ This could be the reason for a hydrolytic cleavage in the reaction with traces of moisture present in nitrogen as impurity. In the case of the nitrate complex, the thermogram is relatively complicated and involves four steps. The first step corresponds to the loss of water of crystallization, second and third steps to stepwise loss of ligand whereas the fourth step involves a hydrolytic reaction of copper (II) nitrate to form $\mathrm{Cu}(\mathrm{OH}) \mathrm{NO}_{3}$, thereby releasing $\mathrm{HNO}_{3}$. In our earlier study it was observed that in bis-(N-phenyl 3,5-dimethylpyrazole) copper (II) nitrate loses $\mathrm{N}$-phenyl 3,5-dimethylpyrazole ligands and $\mathrm{N}_{2} \mathrm{O}_{3}$ on heating to $450^{\circ} \mathrm{C}$ to finally give cupric oxide. ${ }^{31}$
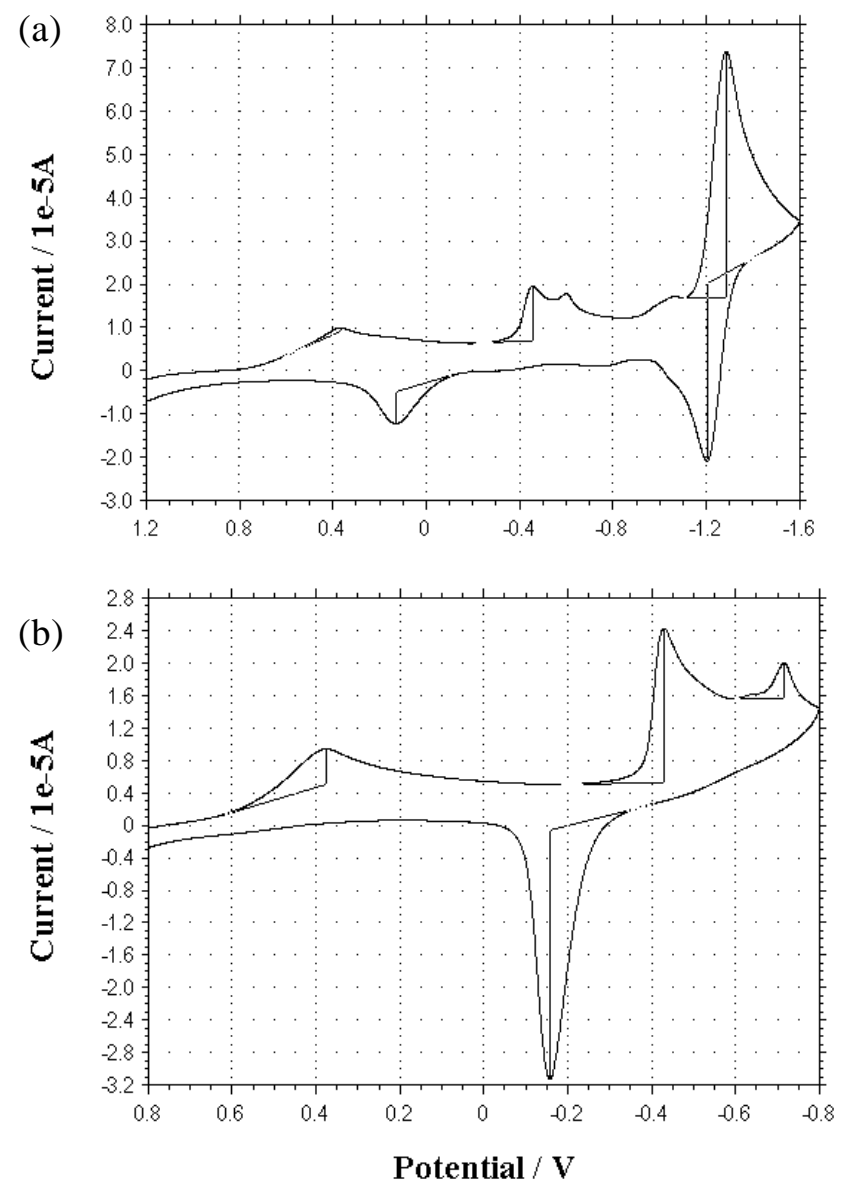

Figure 2. Cyclic voltammogram of (8) (a) and (10) (b) in acetonitrile TBAP as supporting electrolyte; platinum electrodes as working electrodes and $\mathrm{Ag} / \mathrm{AgCl}$ as reference electrode (+ve scan, $100 \mathrm{mV} / \mathrm{s}$ ) and potentials are with respect to the ferrocene couple. 
The electrochemical study of the complex has shown no significant change in the reversible redox couple of the ligand. In the case of complex (10) the quasi-reversible $\mathrm{Cu}(\mathrm{I}) / \mathrm{Cu}(\mathrm{II})$ couple occurs at a different position as compared to the similar couple in compounds (8) and (9). This may occur due to the non-interacting nature of the naphthalimide and phthalimide units at a remote site with the redox active metal site. Moreover, the phthalimide derivative (7) is also redox inactive in the region of $+1.0 \mathrm{~V}$ to $-1.6 \mathrm{~V}$ (vs SCE). Redox peaks of complexes $(\mathbf{8})$ and (9) in $+1.0 \mathrm{~V}$ to $-1.6 \mathrm{~V}$ region from both the metal centers and the ligand are well separated from each other and can be easily distinguished (figure 2).

In conclusion, the reversible redox couples of the 1,8-naphthalimide derivatives presented in this manuscript are not affected by substituents attached to the $\mathrm{N}$-atom or the presence of a redox centre at a remote place, but are affected by supramolecular assembly. This allows scope for use of these substrates as electrochemical probes.

\section{Acknowledgements}

The authors thank the Department of Science and Technology, New Delhi, for financial support.

\section{References}

1. Grabchev I, Chovelon J M, Bojinov V and Ivanova G 2003 Tetrahedron 599591

2. Grabchev I, Chovelon J M and Bojinov V 2004 Polym. Adv. Technol. 15382

3. Carroll J B, Gray M, McMenimen K A, Hamilton D C and Rotello V M 2003 Org. Lett. 53177

4. Davies J E D, Finocchiaro P and Herbstien F H 1984 in Inclusion compounds (eds) J L Atwood, J E D Davies and D D MacNicol (New York: Academic Press), vol. 2, pp. 407-453

5. Kishikawa K, Tsubokura S, Kohmoto S, Yamamoto $\mathrm{M}$ and Yamguchi K 1999 J. Org. Chem. 647568

6. Hayashida O, Sebo L and Rebek J 2002 J. Org. Chem. 678291

7. Kishikawa K, Tsubokura S, Kohmoto S, Yamamoto M and Yamguchi K 1999 J. Org. Chem. 647568

8. Barna M F, Cacho M, Garcia M A, de Pascual-Teresa B, Ramos A, Acero N, Llinares F, Munoz-Mingarro
D, Abradelo C, Rey-Stolle M-F and Yuste M 2002 J. Med. Chem. 455813

9. Barna M F, Cacho M, Ramos A, Dominguez M T, Pozuelo J M, Abradelo C, Rey-Stolle M F, Yuste M, Carrasco C and Bailly C 2003 Org. Biomol. Chem. 1 648

10. Ramachandram B, Saroja G, Sankaran N B and Samanta A 2000 J. Phys. Chem. B104 11824

11. de Sousa M, Kluciar M, Abad S, Miranda M A, de Castro B and Pischel U 2004 Photochem. Photobiol. Sci. 3639

12. Licchelli M, Biroli A O, Poggi A, Sacchi D, Sangermani C and Zema M 2003 J. Chem. Sci., Dalton Trans. 4537

13. Sankaran N B, Banthia S and Samanta A 2002 Proc. Indian Acad. Sci. (Chem. Sci.) 114539

14. Jia L H, Zhang Y, Guo X F and Qian X H 2004 Tetrahedron Lett. 453969

15. Hutchins R O, Wei J and Rao S J 1994 J. Org. Chem. 594007

16. McAdam C J, Morgan J L, Murray R E, Robinson B H and Simpson J 2004 Aust. J. Chem. 57525

17. Sen S E and Roach S L 1995 Synthesis 756

18. North M 1996 Contemp. Org. Syn. 3, 323

19. Sakamoto T and Pac C 2001 J. Org. Chem. 6694

20. Griesbeck A G and Mauder H 1992 Angew. Chem., Int. Ed. Engl. 3173

21. Griesbeck A G, Mauder H and Muller I 1992 Chem. Ber. 1252467

22. Griesbeck A G, Hirt J, Peters K, Peters E-M and Schnering H G 1996 Chem. Eur. J. 21388

23. Gosztola D, Niemczyk M P, Svec W, Lukas A S and Wasielewski M R 2000 J. Phys. Chem. A104 6545

24. Parra V, Del Cano T, Rodriguez-Mendez M L, de Saja J A and Aroca R F 2004 Chem. Mater. 16358

25. Johansson O, Borgstrom M, Lomoth R, Palmblad M, Bergquist J, Hammarstrom L, Sun L C and Akermark B 2003 Inorg. Chem. 422908

26. Barooah N, Sarma R J and Baruah J B 2003 Cryst. Growth Des. 3639

27. Cooke G, Sindelar V and Rotello V M 2003 Chem. Commun. 752

28. Martens C F, Schenning A P H J, Feiters M C, Berens $\mathrm{H}$ W, van der Linden J G M, Admiraal G, Beurskens P T, Kooijman H, Spek A L and Nolte R J 1995 Inorg. Chem. 344735

29. Francisco R H P, Lechat J R and Mascarenhas Y P 1979 Acta Crystallogr. B35 1468

30. Baillie M J, Brown D H, Moss K C and Sharp D W A 1965 J. Chem. Soc., Chem. Commun. 91

31. Barooah N, Sharma S, Sarma B C and Baruah J B 2004 Appl. Organomet. Chem. 18, 440 